\title{
Performansi Turbin Angin Poros Vertikal Tipe Savonius 2 Tingkat Untuk Pengisian Baterai Sebagai Penerangan Lampu Perahu Nelayan Kota Padang
}

\author{
Rizki Muhamad Amsor ${ }^{a}$, Iskandar R. ${ }^{a}$ \\ a Jurusan Teknik Mesin, Fakultas Teknik, Universitas Andalas, Padang
}

\section{INFORMASI ARTIKEL}

Sejarah Artikel:

Diterima Redaksi: 05 Februari 2017

Revisi Akhir: 01 Maret 2017

Diterbitkan Online: 01 April 2017

\begin{tabular}{l} 
KATA KUNCI \\
\hline Wind turbines \\
Renewable energy \\
Savonius \\
KORESPONDENSI \\
\hline
\end{tabular}

E-mail: rmuhamadamsor@gmail.com

\begin{abstract}
A B S T R A C T
The biggest energy source used today is still predominantly derived from fossil fuels, which is known fossil energy resources are non-renewable so that over time will run out. Therefore, the nowadays conditions should utilize energy sources that are renewable. One of the renewable energy sources that are environmentally friendly and are easy to come is wind energy, which its utilization uses wind turbines. Wind turbines can be used for generating electricity so that it can overcome one of the problems of energy for the fishermen in Padang. Padang has a low to medium wind speeds, so that the suitable wind turbine is Savonius turbine type. The research was done by creating a model of Vertical Axis Wind Turbines (TASV) Savonius type with 2 stages of blades made of aluminum material. Each rotor is having $50 \mathrm{~cm}$ diameter and $80 \mathrm{~cm}$ height. Parameter studies that measured are wind speed, rotor rotational speed, turbine force, voltage and current in the generator. Meanwhile, the observation is held on Air Tawar Padang, West Sumatra. From the performance of the Savonius wind turbine in this research is got $5.9 \mathrm{~m} / \mathrm{s}$ maximum wind speed, 225,8 rpm maximum turbine rotation, $4.7 \%$ the highest $C p$ and 2 watts the highest power and can catch 160.2 watts the wind power.
\end{abstract}

\section{PENDAhuluan}

Energi merupakan kebutuhan utama sepanjang sejarah manusia. Hingga saat ini kebutuhan terhadap energi semakin meningkat. Di Indonesia sumber energi dari fosil menjadi pilihan utama untuk dimanfaatkan. Pertumbuhan penduduk Indonesia yang sangat tinggi tidak diimbangi dengan ketersediaan minyak mentah yang ada di alam, akibatnya cadangan minyak bumi semakin menipis yang memicu terjadinya krisis energi. Salah satu upaya untuk mengatasi krisis energi adalah mengurangi ketergantungan terhadap sumber energi fosil dengan cara memanfaatkan sumber energi alternatif. Misalnya energi air, energi angin, energi matahari, energi panas bumi dan energi nuklir.

Energi angin merupakan salah satu sumber energi terbarukan yang dapat menjawab kebutuhan energi alternatif. Kota Padang merupakan Ibukota Provinsi Sumatera Barat yang berada pada garis pantai, banyak dari masyarakat daerah sekitar pantai berprofesi sebagai nelayan. Pada saat sekarang ini nelayan kerap dihadapkan pada masalah besarnya pengeluaran saat melaut. Masyarakat nelayan tradisional umumnya menggunakan solar untuk mesin perahu atau kapal, serta minyak tanah untuk bahan bakar lampu petromaks. Permasalahan dicabutnya subsidi minyak tanah akan menjadikan 
permasalahan besar bagi nelayan di Indonesia, karena seluruh kegiatannya mengunakan minyak tanah, seperti untuk menangkap ikan di laut nelayan mengandalkan cahaya yang dihasilkan oleh lampu petromak. Dari permasalahan tersebut, maka perlu dicarikan solusi dengan memanfaatkan energi angin pada saat nelayan berlayar waktu sore hingga malam hari. Energi angin dapat dimanfaatkan untuk menghasilkan energi listrik dengan cara memutar turbin angin yang dihubungkan ke generator kemudian hasilnya disimpan dalam elemen penyimpan (baterai), sehingga bisa dimanfaatkan untuk menghidupkan lampu jenis LED.

Sementara itu berdasarkan hasil pengukuran Badan Meteorogi, Klimatologi dan Geofisika (BMKG) wilayah Kota Padang pada tahun 2010 memiliki kecepatan angin berkisar antara 0,77-7,70 m/s. Kecepatan ini tergolong jenis kecepatan angin rendah hingga menengah, sehingga turbin angin yang cocok digunakan adalah jenis turbin poros vertikal seperti savonius.

Turbin angin poros vertikal tipe savonius adalah tipe turbin angin yang mampu mulai berputar pada kecepatan angin rendah karena memiliki selfstarting yang tinggi [1]. Turbin angin ini memiliki kontruksi sederhana sehingga dapat diaplikasikan pada skala kecil hingga menengah yang dapat diterapkan dan ditempatkan dibeberapa posisi di perahu nelayan. Turbin angin akan dihubungkan ke generator, kemudian energi listrik yang dihasilkan oleh generator disimpan dalam elemen penyimpan energi listrik (baterai). Pada penelitian ini dibuat turbin poros vertikal savonius dengan 2 tingkat dimana pada penelitian sebelumnya hanya perancangan dan pembuatan prototipe turbin angin sumbu vertikal tipe savonius yang dilakukan oleh S. Aviv Al Rasyid [2].

\section{TINJAUAN PUSTAKA}

\subsection{Energi Angin}

Energi angin adalah energi yang terkandung pada massa udara yang bergerak. Energi angin berasal dari energi matahari. Pemanasan bumi oleh sinar matahari menyebabkan perbedaan massa jenis udara. Perbedaan massa jenis ini menyebabkan perbedaan tekanan pada udara sehingga akan terjadi aliran fluida dan menghasilkan angin. Kondisi aliran angin dipengaruhi oleh medan atau permukaan bumi yang dilalui oleh aliran angin dan perbedaan temperatur permukaan bumi.

\subsection{Turbin Angin}

Turbin angin merupakan salah satu alat yang mekanisme kerjanya memanfaatkan energi angin.Di negara-negara maju, sudah banyak pemanfaatan turbin angin sebagai pembangkit listrik. Turbin angin yang digunakan dapat menghasilkan kapasitas listrik yang tinggi yaitu mencapai ratusan megawatt. Di negara-negara berkembang, penggunaan turbin angin berada dalam skala riset.

Turbin angin adalah sebuah alat yang memanfaatkan energi kinetik angin dan mengubahnya ke dalam bentuk energi gerak putaran rotor dan poros generator untuk menghasilkan energi listrik. Energi gerak yang berasal dari angin akan diteruskan menjadi gaya gerak dan torsi pada poros generator yang kemudian akan dihasilkan energi listrik [3].

Berdasarkan arah sumbu geraknya, turbin angin terbagi menjadi 2, yaitu turbin angin sumbu horizontal dan turbin angin sumbu vertikal. Turbin angin sumbu horizontal memiliki sumbu putar yang sejajar dengan tanah. Turbin angin sumbu vertikal memiliki sumbu putar yang arahnya tegak lurus dengan tanah.

Turbin angin dibagi menjadi dua kelompok utama berdasarkan arah sumbu:

1. Turbin Angin Sumbu Horizontal

Turbin Angin Sumbu Horizontal (TASH) memiliki poros rotor utama dan generator listrik di puncak menara. Turbin berukuran kecil diarahkan oleh sebuah baling-baling angin (baling-baling cuaca) yang sederhana, sedangkan turbin berukuran besar pada umumnya menggunakan sebuah sensor angin yang digandengkan ke sebuah servo motor. Sebagian besar memiliki sebuah gearbox yang 
mengubah perputaran turbin yang pelan menjadi lebih cepat berputar.

\section{Turbin Angin Sumbu Vertikal}

Kendala penggunaan turbin angin adalah kecepatan angin dan arah angin yang berubahubah sepanjang waktu.Oleh karena itu, turbin angin yang baik adalah turbin yang dapat menerima angin dari segala arah selain itu juga mampu bekerja pada angin dalam kecepatan yang rendah salah satunya Turbin Angin Sumbu Vertikal (TASV). Turbin ini memiliki efisiensi yang lebih kecil dibandingkan dengan turbin angin sumbu horizontal.

Tipe Savonius TASV seperti yang ditunjukkan pada Gambar 2.1, diciptakan oleh seorang insinyur Finlandia SJ Savonius pada tahun 1929. Turbin TASV ini merupakan jenis yang paling sederhana dan menjadi versi besar dari anemometer. Turbin Savonius dapat berputar karena adanya gaya dorong dari angin, sehingga putaran rotor pun tidak akan melebihi kecepatan angin. Jenis turbin ini cocok untuk aplikasi daya yang rendah dan biasanya digunakan pada kecepatan angin yang berbeda.

Keunggulan dari ketiga rotor di atas adalah:

a. Rotor Savonius tipe-U memiliki kecepatan putar tinggi karena angin dapat disirkulasikan terpusat di tengah atau pusat batang, tetapi kurang efisien dibandingkan dua tipe lainnya.

b. Rotor Savonius tipe-S dapat dirancang dengan mudah dari drum. Desain ini lebih efisien dari Savonius U karena beberapa aliran udara dibelokkan oleh kedua sudu lalu keluar pada salah satu sisinya dengan kata lain aliran udara sama besar pada kedua bilah sudu.
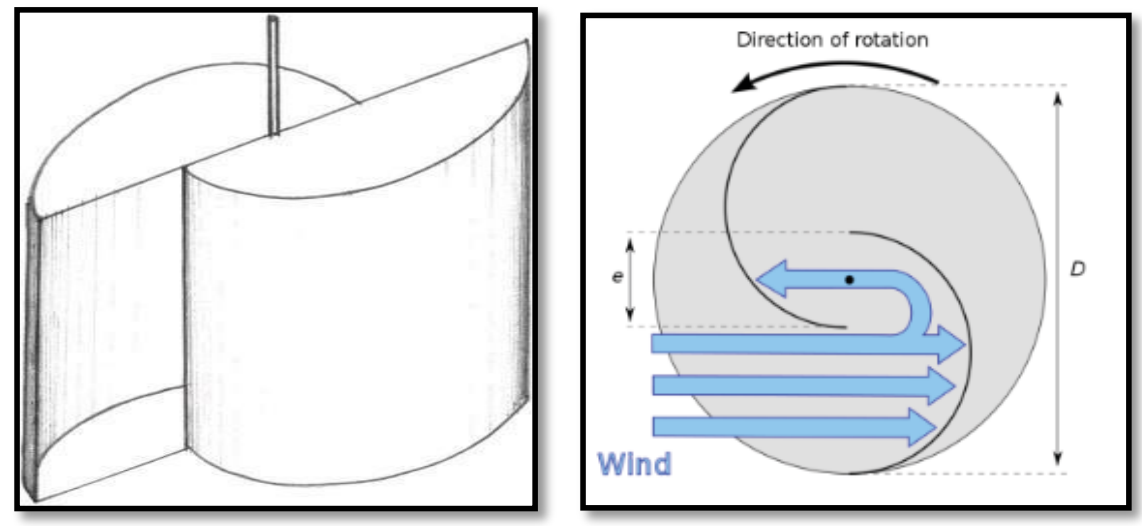

Gambar 1. Prinsip kerja Turbin Angin Sumbu Vertikal Savonius [3]

Dalam perkembangannya rotor Savonius ini mengalami perubahan dalam bentuk rotor, seperti Gambar 2.

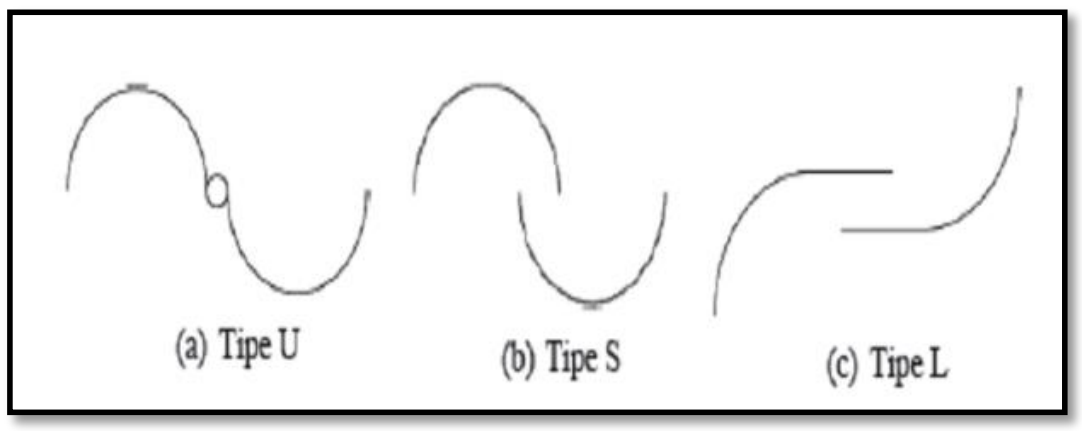

Gambar 2. Bentuk rotor [4] 
c. Rotor Savonius tipe-L ini adalah desain yang paling efisien dari turbin angin Savonius. Savonius tipe-L tidak hanya memiliki keunggulan dari udara yang dibelokkan menjadi dua kali tetapi juga sebagian vanes bertindak seperti sebuah airfoil ketika berada di tepi, membuat efek gaya angkat kecil sehingga meningkatkan efisiensi.

\subsection{Daya Angin}

Daya angin, $P_{a}$ didefenisikan sebagai perkalian antara mass flow rate, $\rho$ Av dengan energi kinetik per unit massa $1 / 2 v^{2}$ Angin [4], secara matematis dapat ditulis seperti pada persamaan 1 .

$P_{a}=\frac{1}{2} \rho A v^{3}$

Daya angin adalah daya input yang dibawa oleh angin yang akan dikonversikan oleh rotor turbin menjadi daya mekanik putaran poros.

\subsection{Daya Mekanik Putaran Poros}

Daya mekanik putaran poros, $P_{m}$ adalah daya yang diakibatkan putaran dari turbin yang dilalui oleh angin. Daya mekanik didapatkan dari hubungan torsi (T) dengan kecepatan sudut turbin angin. Persamaan daya mekanik dapat dilihat pada persamaan 2 .

$P_{m}=\omega \cdot F \cdot r$
Dimana $\omega$ adalah kecepatan sudut, dapat dihitung dengan menggunakan rumus:

$\omega=\frac{2 \pi n}{60} r$

dengan $\mathrm{n}(\mathrm{rpm})$ merupakan putaran rotor turbin.

\subsection{Daya Listrik}

Daya listrik, $P_{g}$ adalah daya yang keluar dari generator berupa tegangan $(\mathrm{V})$ dan arus (I). Dengan mengukur besarnya tegangan yang dihasilkan, dapat diketahui besarnya daya generator.

$$
P_{g}=V . I
$$

\subsection{Tip Speed Ratio}

Tip speed ratio (TSR), $\lambda$ adalah rasio ujung rotor terhadap kecepatan angin bebas. Untuk kecepatan angin nominal yang tertentu, tip speed ratio akan berpengaruh pada kecepatan rotor. Turbin angin tipe lift akan memiliki tip speed ratio yang lebih besar dibandingkan dengan turbin tipe drag. Besarnya tip speed ratio dapat dihitung dengan persamaan 5 .

$$
\lambda=\frac{\omega r}{v}
$$

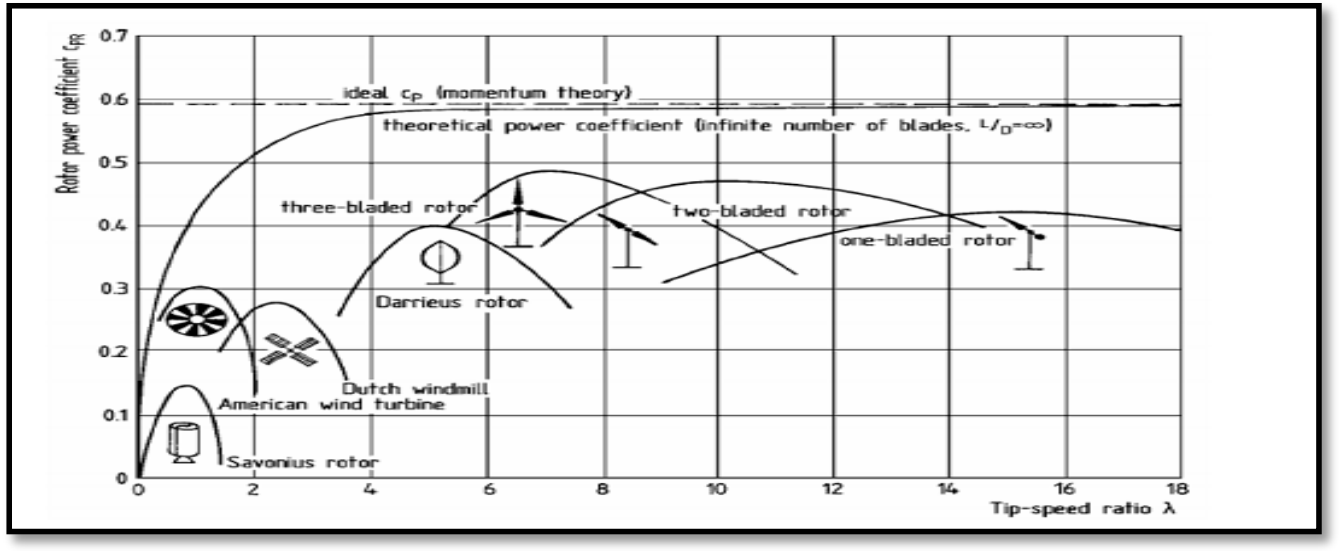

Gambar 3. Nilai tip speed ratio dan koefisien daya pada berbagai jenis turbin angin [4] 
Gambar 2.3 berikut menunjukan variasi nilai tip speed ratio dan koefisien daya, $\mathrm{Cp}$ untuk berbagai macam turbin angin.

\subsection{Koefisien Daya}

Untuk menyatakan performa suatu turbin angin biasanya dinyatakan dalam istilah koefisen daya, $\mathrm{C}_{\mathrm{p}}$ yang merupakan perbandingan antara daya yang dihasilkan oleh turbin terhadap daya angin yang diperoleh. Koefisen Daya turbin angin dapat dihitung dengan rumus persamaan 6 .

$C_{p}=\frac{P_{m}}{P_{a}}$

\section{METODOLOGI}

Dari proses perencanaan yang telah dilakukan didapatkan hasil desain turbin, meliputi rotor angin, (terdiri dari sudu-sudu turbin), poros, sistem transmisi, dan generator. Sudu rotor yang dibuat terdiri dari dua tingkat dengan jumlah sudu 2 per tingkat. Sudu turbin dibuat dari pelat alumunium dengan tebal $1 \mathrm{~mm}$. Tinggi rotor $80 \mathrm{~cm}$ dan diameternya $50 \mathrm{~cm}$. Rotor turbin dilengkapi dengan sebuah poros pejal berdiameter $20 \mathrm{~mm}$. Poros turbin ini melekat pada cakram pemegang sudu dan diperkuat dengan menggunakan 2 buah bearing, yang berfungsi untuk menahan gaya aksial pada saat sudu berputar. Puli berfungsi untuk meneruskan energi mekanik putaran poros turbin menuju ke generator. Puli ini terbuat dari bahan aluminium berdiameter 11 inchi dan disesuaikan dengan sambungan puli pada generator listrik dengan diameter 3 inci. Jenis puli yang digunakan adalah tipe v-belt dengan maksud agar tidak terjadi slip puli. Sabuk atau belt yang digunakan menyesuaikan bentuk alur dari puli. Generator listrik, berfungsi untuk merubah energi mekanik putaran poros turbin menjadi energi listrik.

Desain model prototipe turbin angin yang dibuat dengan jumlah sudu 2 pada tingkat turbin yang pertama dan untuk tingkat kedua serta turbin yang dibuat ditampilkan pada Gambar 4.
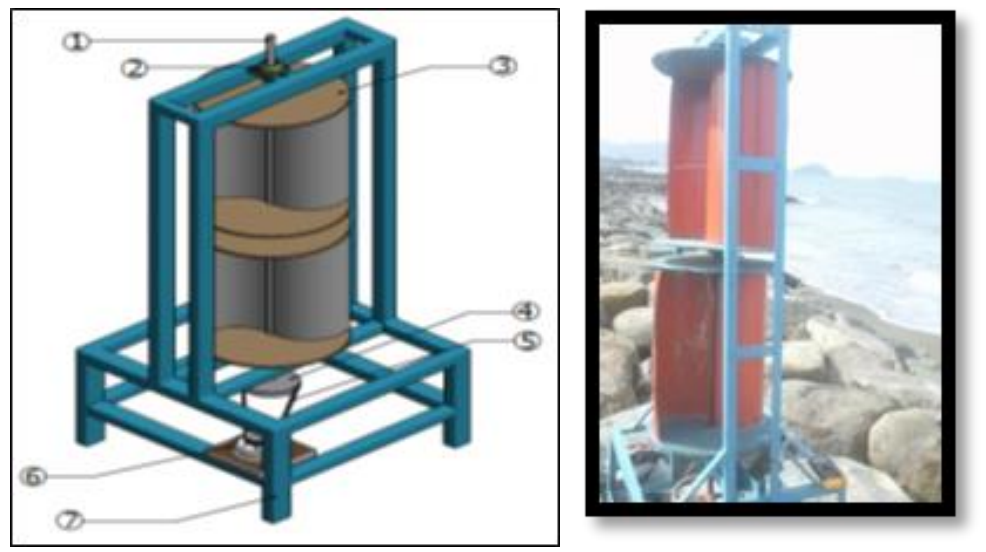

Gambar 3. Turbin Angin Savonius 2 Tingkat

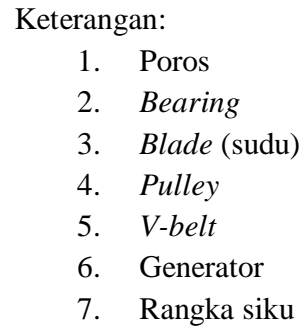

6. Generator

7. Rangka siku 


\subsection{Alat Ukur Pengujian}

Dalam pengujian turbin sumbu vertikal tipe Savonius ini terdapat berbagai macam alat ukur yang digunakan, antara lain:

1. Anemometer berfungsi untuk mengukur kecepatan angin.

2. Tachometer berfungsi untuk mengukur putaran (rpm). Pengukuran dilakukan pada poros turbin angin vertikal tipe savonius.

3. Multimeter, berfungsi untuk mengukur kuantitas listrik yang sering dikenal sebagai VOM (Volt-Ohm meter) yang dapat mengukur tegangan (voltmeter), hambatan (ohm-meter), maupun arus (amperemeter).

\subsection{Prosedur Pengujian}

Pengujian untuk mengetahui performansi (unjuk kerja) dari turbin angin savonius yang dibuat dilakukan di daerah pantai Air Tawar Kota Padang dari pukul 09.00 WIB sampai pukul 17.00 WIB, dengan prosedur pengujian sebagai berikut:

1. Siapkan alat uji yaitu turbin angin vertikal tipe savonius 2 tingkat 2 sudu.

2. Siapkan alat ukur (anemometer, tachometer, multimeter) dan ambil data secara bersamaan.

3. Catat data setiap lima menit.
4. Lakukan pengolahan data untuk mendapatkan daya angin, daya listrik, daya mekanik, koefisien daya dan tip speed ratio.

\section{HASIL DAN PEMBAHASAN}

\subsection{Hubungan Waktu Terhadap Kecepatan Angin}

Dari pengujian kecepatan angin yang dilakukan pada hari Minggu tanggal 25 September 2016 di daerah pantai Air Tawar Padang diperoleh hasil seperti pada Gambar 4. Dari Gambar 4. tersebut dapat dilihat bahawa kecepatan maksimum terdapat pada pukul 13.35 WIB. Keadaan angin di Kota Padang cenderung meningkat setiap jamnya dan kecepatan angin dari pukul 09.00 WIB sampai pukul 17.00 WIB berkisar antara 3,1 $-5,9 \mathrm{~m} / \mathrm{s}$. Sesuai dengan data yang diperoleh dapat disimpulkan kecepatan rata-rata di Kota Padang khususnya memang kondisi kecepatan rendah hingga menengah.

Kondisi data kecepatan angin Indonesia khususnya Kota Padang mempunyai kecepatan angin rendahmenengah, sehingga turbin angin savonius ini sangat cocok untuk diterapkan karena lebih mudah berputar pada kondisi kecepatan angin rendah.

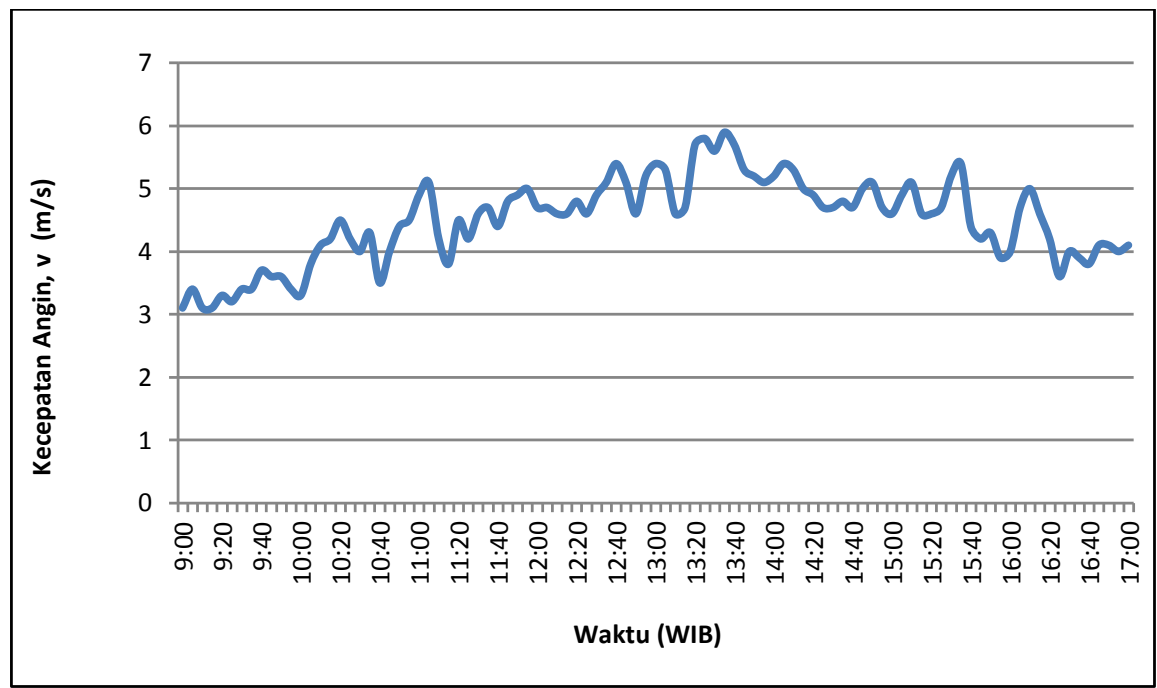

Gambar 4. Hubungan waktu terhadap kecepatan angin pada tanggal 25 September 2016 


\subsection{Pengaruh Kecepatan Angin Terhadap Putaran Turbin}

Kecepatan angin akan berhubungan dengan gerak putar dari rotor. Pengaruh kecepatan angin terhadap putaran rotor turbin ditampilkan pada Gambar 5 dan hubungan waktu dengan putaran yang dihasilkan ditampilkan pada Gambar 6.

Dari Gambar 5 dapat dikatakan bahwa kecepatan angin berbanding lurus dengan putaran yang dihasilkan, artinya semakin besar kecepatan angin yang diberikan, maka semakin besar pula putaran turbin yang dihasilkan, semakin besar energi yang diberikan oleh angin terhadap turbin maka energi yang dapat dikonversikan turbin menjadi putaran semakin meningkat. Dari Gambar 5 tersebut dapat dikatakan bahwa putaran maksimal yang dihasilkan turbin angin sebesar 225,8 rpm dengan kecepatan angin maksimal yaitu $5,9 \mathrm{~m} / \mathrm{s}$, sedangkan untuk putaran minimal yang terjadi pada kecepatan yaitu $3,1 \mathrm{~m} / \mathrm{s}$ sebesar $89,8 \mathrm{rpm}$.

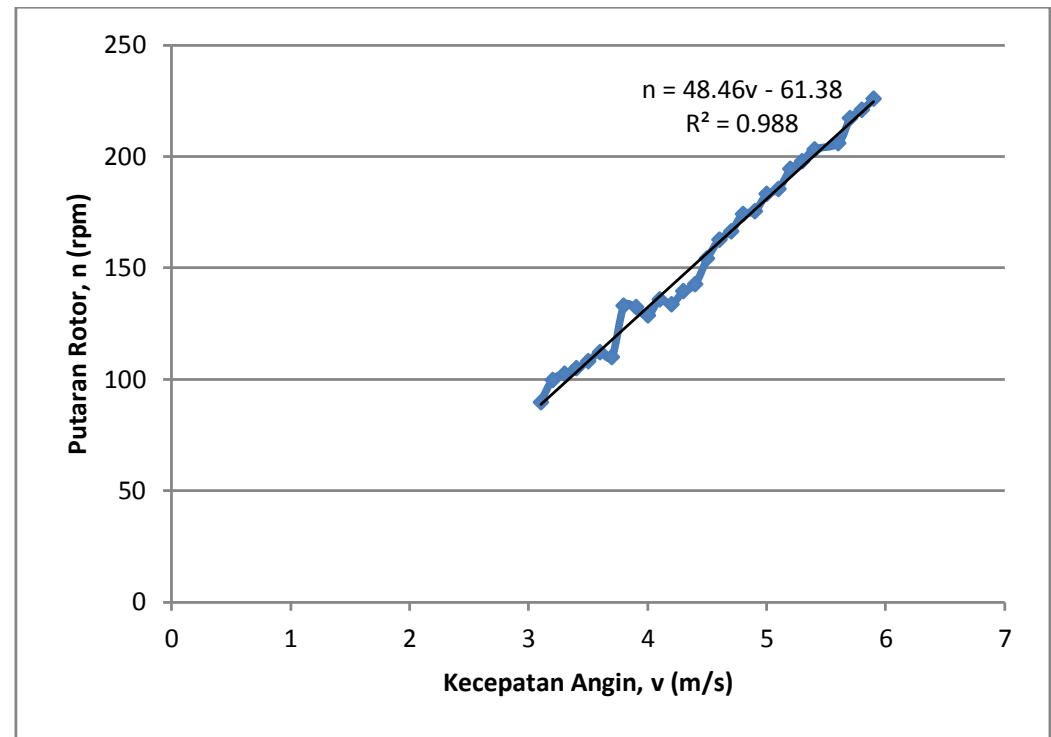

Gambar 5. Pengaruh kecepatan angin terhadap putaran rotor turbin

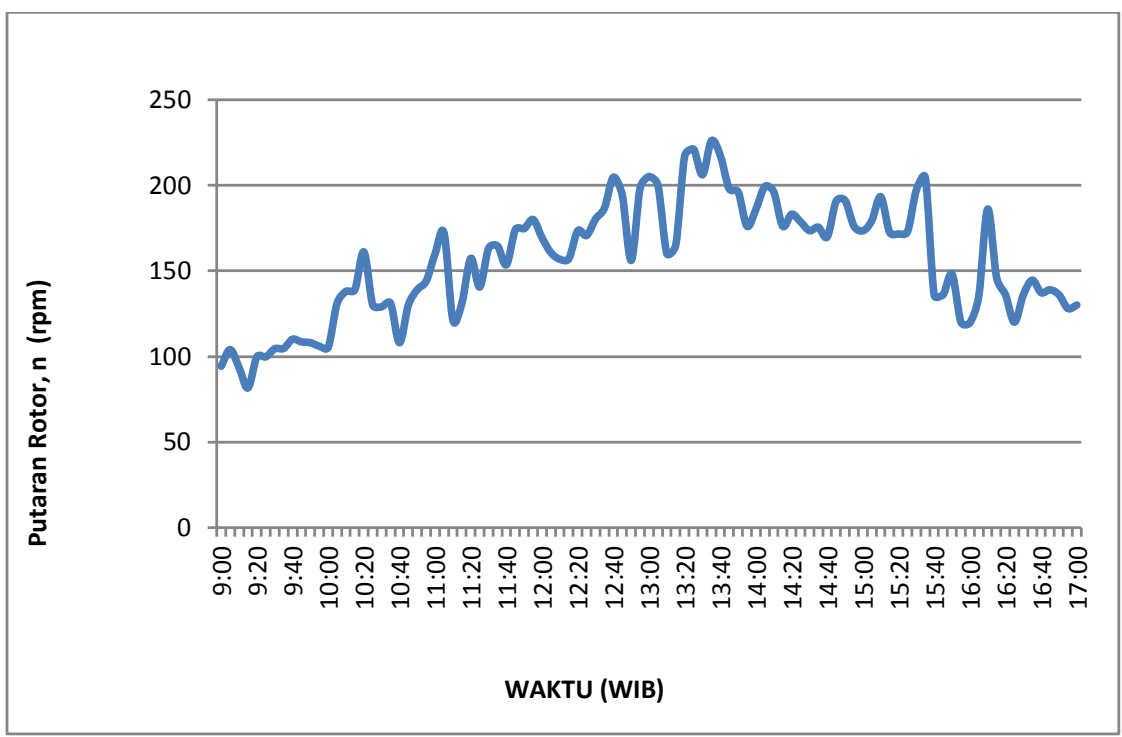

Gambar 6. Hubungan waktu dengan putaran rotor turbin Savonius 


\subsection{Koefisien Daya dan Tip Speed Ratio}

Pada Gambar 7 dapat dilihat pengaruh kecepatan angin terhadap koefisien daya turbin. Koefisien daya yang dihasilkan lebih dari $1 / 3$ dari nilai maksimum yang dinyatakan oleh Hau yaitu 0,047 $(4,7 \%)$. Hal ini disebabkan oleh masih banyaknya rugi-rugi dari komponen turbin yang digunakan. Dari gambar tersebut juga dapat dilihat bawah koefisien daya berbanding terbalik dengan kecepatan angin, dimana semakin besar kecepatan angin maka semakin kecil koefisien daya yang dihasilkan. Hal ini disebabkan oleh pertambahan daya mekanik jauh lebih kecil dari pertambahan daya angin, seperti yang ditampilkan pada Gambar 8. Dari gambar dapat dilihat bahwa pertambahan daya angin rata-rata sebesar $7,42 \%$, sementara pertambahan daya mekanik rata-rata sebesar $2,93 \%$.

Kemampuan setiap jenis turbin angin berbeda-beda, kemampuan jenis turbin angin untuk menyerap energi angin memiliki batas kemampuan terhadap kecepatan angin sehingga setelah mencapai koefisien daya maksimum dari turbin tersebut, maka nilai koefisien daya akan menurun jika kecepatan angin bertambah. Dari penelitian, pengaruh tip speed ratio terhadap koefisien daya ditampilkan pada Gambar 9. Hasil yang diperoleh masih berada dalam batasan yang dinyatakan oleh Hau.

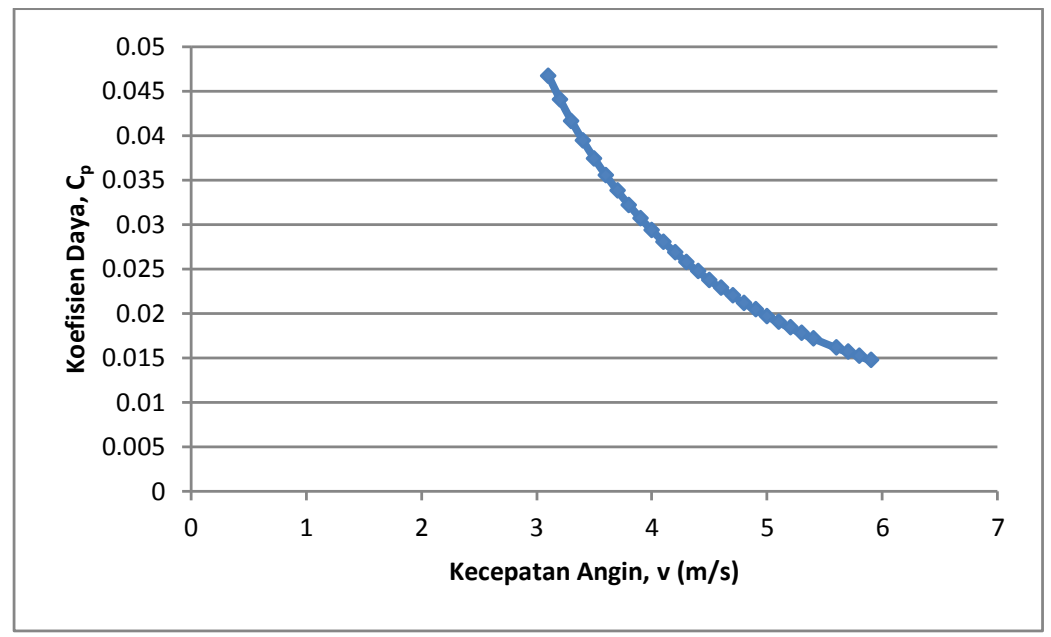

Gambar 7. Pengaruh kecepatan angin terhadap koefisien daya

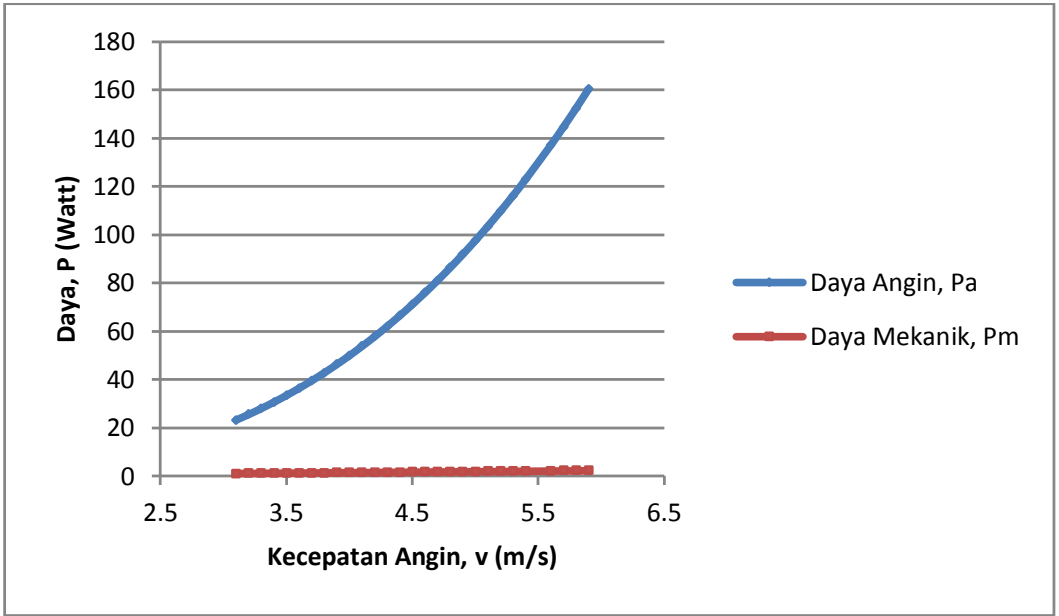

Gambar 8. Pengaruh kecepatan angin terhadap daya 


\subsection{Perusahaan Kecepatan Angin Terhadap Daya Listrik}

Dari grafik yang diperoleh pada Gambar 9, tegangan listrik yang dihasilkan oleh generator listrik berubah sesuai dengan karakteristik angin di Pantai Air Tawar Padang.

Dari hasil yang ditunjukan pada Gambar 9 keluaran tegangan tegangan listrik tertinggi diperoleh sebesar 4 Volt pada pukul 13.25 dan tegangan listrik terendah sebesar 0,6 Volt pada pagi hari. Dari grafik dapat dilihat bahwa kecepatan angin sebanding dengan tegangan listrik yang dihasilkan, artinya bahwa peningkatan kecepatan angin seiring dengan peningkatan tegangan listrik yang dihasilkan. Hal ini tidak terlepas dari putaran, peningkatan putaran pada turbin sejalan dengan peningkatan putaran pada generator. Ketika poros generator mulai berputar maka akan terjadi perubahan fluks pada stator yang akhirnya akan menghasilkan tegangan dan arus tertentu yang nilainya juga berbanding lurus dengan kecepatan angin.

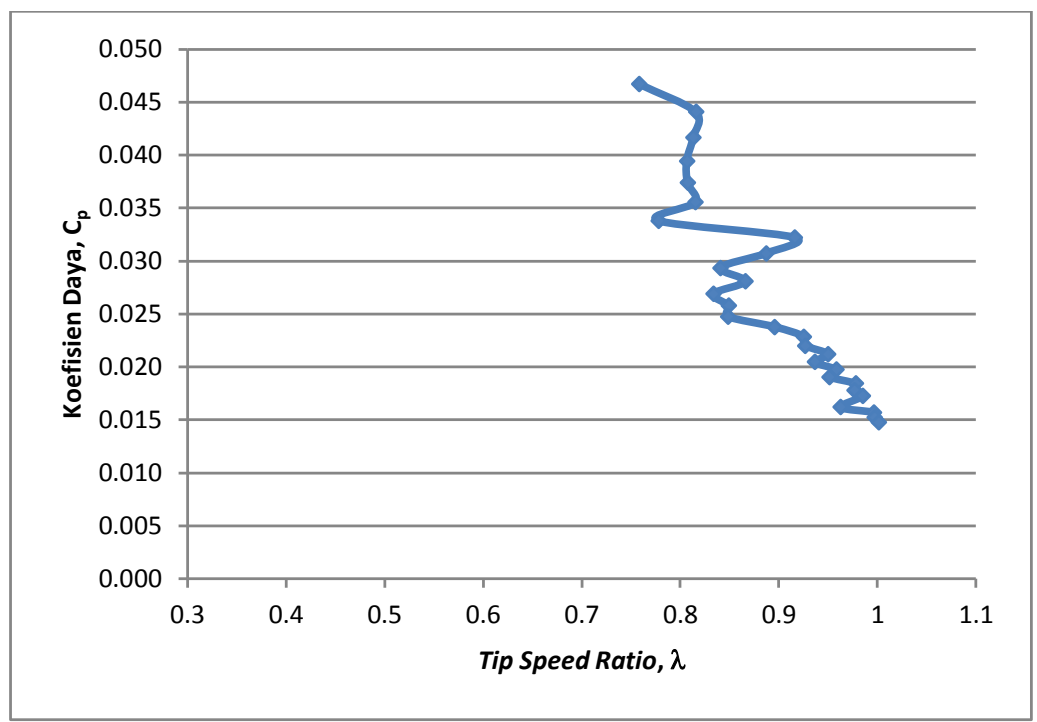

Gambar 8. Hubungan tip speed ratio terhadap koefisien daya

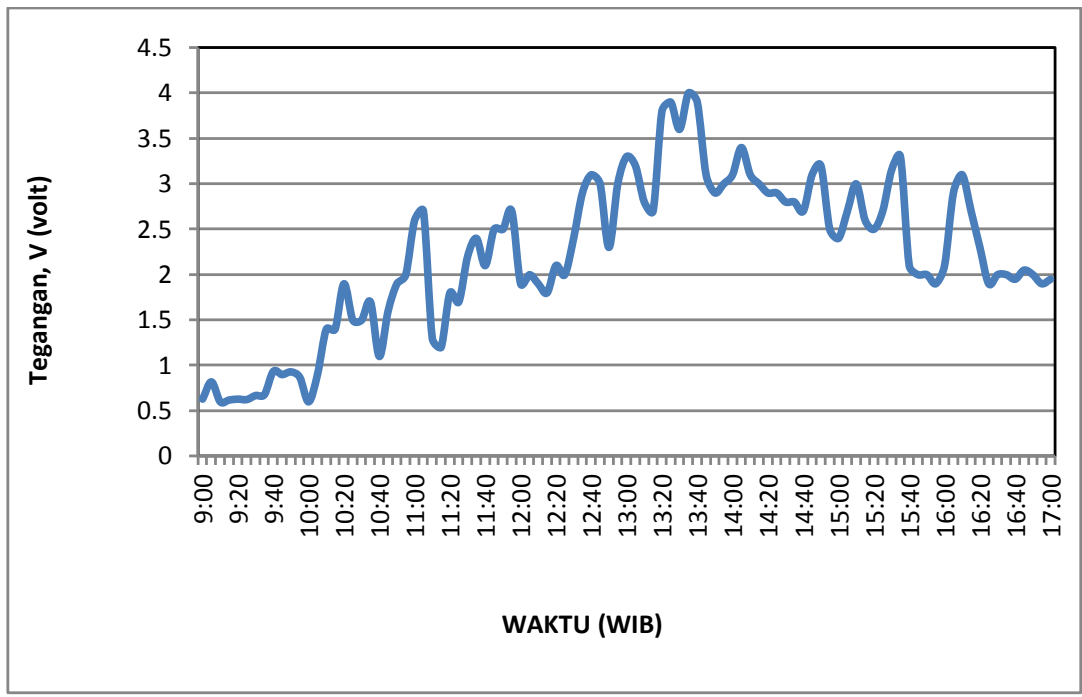

Gambar 9. Hubungan waktu dengan tegangan listrik yang dihasilkan 
Pada Gambar 10 ditunjukkan bahwa daya listrik yang dihasilkan mempunyai karakteristik yang sama dengan tegangan listrik, karena tegangan listrik berbanding lurus dengan daya listrik seperti yang ditunjukkan oleh persamaan 4. Daya listrik tertinggi yang dihasilkan adalah sebesar 2 Watt dengan kecepatan angin sebesar $5,9 \mathrm{~m} / \mathrm{s}$.

Daya yang dihasilkan generator cenderung rendah, hal ini dipengaruhi banyak faktor diantaranya adalah banyaknya rugi-rugi gesekan yang disebabkan dari bearing pencekram poros turbin serta transmisi yang meneruskan gerak putar yang diaplikasikan dari pulley v-belt. Sehingga rotor tidak mampu menggerakan putaran generator dengan maksimal, penyebab lainnya juga dapat ditinjau dari efisiensi kerja dari generator yang digunakan karena dari perancangan generator aksial terdapat pengaruh celah magnet neodyium sebagai rotor terhadap kumparan yang sebagai stator. Dari pengujian langsung dari generator yang digunakan, daya listrik yang dihasilkan sudah dapat menyalakan lampu LED 3 watt. Tetapi pada aplikasinya, daya yang dihasilkan digunakan untuk mengisi ulang baterai, sehingga dapat digunakan oleh nelayan sebagai penerangan di waktu malam.

\section{KESIMPULAN}

Dari penelitian yang telah dilakukan terhadap unjuk kerja turbin angin poros vertikal tipe Savonius 2 tingkat maka dapat diambil beberapa kesimpulan sebagai berikut: (1) Kecepatan angin berbanding lurus dengan putaran yang dihasilkan, dimana untuk kecepatan maksimal 5,9 m/s menghasilkan putaran turbin angin sebesar 225,8 rpm dan kecepatan minimal $3,1 \mathrm{~m} / \mathrm{s}$ menghasilkan putaran turbin sebesar 89,8 rpm; (2) Koefisien daya dari turbin Savonius yang digunakan adalah 0,047 (4,7\%); (3) Daya listrik yang dihasilkan adalah 2 watt, yang mana dapat digunakan untuk mengisi ulang baterai lampu penerangan perahu nelayan di kota Padang.

\section{DAFTAR PUSTAKA}

[1] J. Sargolzay. Prediction of The Power Ratio in Wind Turbine Savonius Rotors Using Artifical Neural Networks. Zahedan: Baluchestan University, 2007.

[2] A. Al Rasyid. "Perancangan dan Pembuatan Prototype Turbin Angin Sumbu Vertikal Tipe Savonius". Jurusan Teknik Elektro Fakultas Teknik Universitas Andalas, 2012.

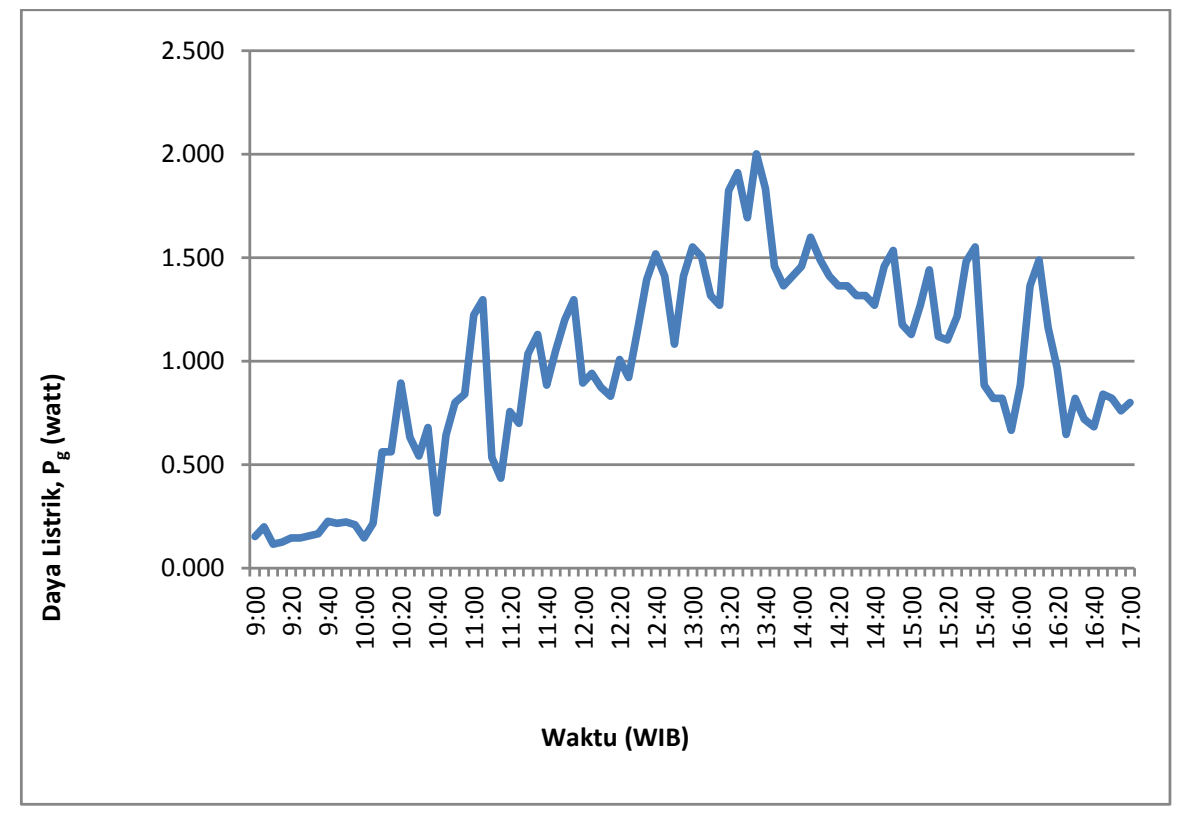

Gambar 10. Hubungan waktu dengan daya listrik generator 
[3] A. Kadir. Energi: Sumber Daya, Inovasi, Tenaga Listrik dan Potensial Ekonomi. Jakarta: Penerbit Universitas Indonesia, 1995.

[4] E. Hau. Wind Turbines Fundamentals, Technologies, Application, Economics, Edisi Kedua", Germany: Springer, 2006.

[5] S. Huda. "Analisa Bentuk Profile dan Jumlah Blade Vertical Axis Wind Turbine terhadap Putaran Rotor untuk Menghasilkan Energi Listrik”, Institut Teknologi Sepuluh Nopember (ITS), 2014.

[6] Y. A. Cengel, J. M. Cimbala. Fluid mechanics: fundamentals and applications. New York: Inc. 1221 Avenue of the Americas, 2006.

[7] A.J. Pradana, M. A. Nugroho. "Rancang Bangun Turbin Angin Vertikal Jenis Savonius dengan Variasi Profil Kurva Blade untuk Memperoleh Daya Maksimum". Jurnal Teknik POMITS, Vol. 7, No. 7, pp. 1-6, 2013. 